\title{
POLA SOSIALISASI PERGURUAN TINGGI DALAM MENINGKATKAN JUMLAH PENERIMAAN MAHASISWA BARU PADA IAIN PALU
}

\author{
Sofyan Bachmid \\ Hamka
}

\begin{abstract}
This artide disasses the effetiveness of the new student admission soialization programon the decision of the prospeetivestudent to enrdl in the State Islamic Institute (IAIN) Palu The prdblem studied is How are the efforts of soialization of new student admissions applied at IAIN Palu? What is the mot effective socialization altempt for student candidates admission at IAIN Palu? This reserch uses survey reserch design combined with descriptive qualitative analysis modd. Data colletion using questionnaire mothod supported by interview and colleting a documetations. The results showed that the socialization efforts applied in IAIN Palu was by utilizing mass media and schod visit. An effective efforts of soialization for introduring institutions to thepublicis unprogrammed in schedules, they used word to word (dbor to dor) and publiaty promtion Nevethdess, reglar programmed soialization modds are hedd regulanly every day before the admission of new students, usually used adketising and "persanal selling" through visits to schools, is still quite effetive. While themain consideration factor for enrolling inIAIN Palu is the availability of carses approprateto their interests.
\end{abstract}

Kata kunci: sosialisasi, penerimaan mahasiswa baru, promosi, pessonal selling 


\section{Pendahuluan}

Peraturan Menteri Pendidikan Nasional Republik Indonesia Nomor 34 Tahun 2010 tentang pola penerimaan mahasiswa baru yang berisi tata cara pelaksanaan seleksi mandiri dan juga kuota mahasiswa, mendorong Perguruan Tinggi Negeri (PTN) menyesuaikan proses penerimaan mahasiswa baru dengan pola seleksi nasional dan seleksi mandiri. Sistem tersebut mendorong PTN berlomba-lomba untuk memperkenalkan program studi masing-masing kepada para calon mahasiswa dengan tujuan merekrut calon mahasiswa yang berprestasi dan sesuai dengan kebutuhan institusi, tak terkecuali dengan IAIN Palu.

Pengembangan kelembangaan IAIN Palu dari Sekolah Tinggi menjadi Institut membuka peluang lebih besar bagi peningkatan jumlah mahasiswa dengan terbukanya sejumlah program studi baru. Tiga tahun terakhir setelah peralihan dari STAIN menjadi IAIN, peningkatan jumlah mahasiswa baru cukup siginifikan.

Namun demikian, peningkatan tersebut masih belum optimal bila dibandingkan dengan potensi mahasiswa baru yang cukup besar untuk wilayah Sulawesi Tengah. Jumlah SMU/ MA di Sulawesi Tengah mencapai 495 dengan total jumlah siswa sebesar 76.239. ${ }^{1}$ Bila diasumsikan 30\% dari jumlah siswa tersebut duduk di kelas III (calon mahasiswa), maka potensi calon mahasiswa baru mencapai 22.872 orang. Lulusan SLTA tersebut diperebutkan oleh banyak perguruan tinggi yang ada di wilayah propinsi Sulawesi Tengah, bahkan oleh seluruh perguruan tinggi di Indonesia. IAIN Palu baru mampu menyerap sekitar 5,5\% dari jumlah lulusan SLTA di Sulawesi Tengah. Tentu saja angka ini merupakan angka kasar mengingat tidak semua lulusan SLTA melanjutkan pendidikan ke jenjang perguruan tinggi. Meski demikian, secara teori IAIN Palu masih berpeluang besar untuk meningkatkan jumlah penerimaan mahasiswa baru secara signifikan. IAIN Palu dituntut untuk melakukan usaha-usaha pemasaran, khususnya usaha sosialisasi secara intensif dan terencana, guna mendekatkan dan memperkenalkan perguruan tinggi ini kepada masyarakat Sulawesi Tengah dan sekitarnya.

\footnotetext{
${ }^{1}$ Sumber data: Dinas Pendidikan dan Kebudayaan Daerah Provinsi Sulawesi Tengah, tahun 2016
} 
Dalam beberapa tahun terakhir upaya sosialisasi penerimaan calon mahasiswa telah dilakukan. Hasilnya, terdapat pertumbuhan jumlah mahasiswa baru dalam 3 tahun terakhir. Pertanyaannya kemudian adalah apakah pertumbuhan tersebut disebabkan oleh program sosialisasi yang dilakukan selama ini, atau oleh hal lain. Hingga saat ini belum pernah dilakukan kajian tentang efektivitas sosialisasi terhadap peningkatan jumlah mahasiswa baru di IAIN Palu.

Sejumlah riset sebelumnya berkenaan dengan penerimaan mahasiswa baru telah banyak dilakukan orang, diantaranya oleh Encep Sopandi yang meneliti tentang Kegiatan Promosi PTS Di Jawa Barat Tahun 2010 titik fokus penelitiannya adalah pada aspek strategi promosi penerimaan mahasiswa baru. Hasil penelitiannya-yang menggunakan pendekatan kualitatif inimemetakanPTS ke dalam dua kategori, PTS besar/ kuat dan PTS kecil/ lemah. PTS besar melakukan kegiatan promosi dengan memperhatikan aspek strategis, yaitu menganilisis situasi internal dan eksternal, penetapan tujuan, pemilihan dan penetapan strategi, mempertimbangkan komponen biaya pendidikan, lokasi dan optimalisasi promosi. Sedangkan PTS kecil hal tersebut belum dilakukan sepenuhnya. Promosi yang dilakukan baru pada kegiatan penyebaran brosur dan iklan di media cetak atau elektronik saja, alasannya adalah keterbatasan dana dan SD M. ${ }^{2}$

Sebuah penelitian lain dilakukan oleh Jayawinangun dkk. pada tahun 2014. Penelitian menggunakan pendekatan kuantitatif ini menyoroti strategi promosi penerimaan mahasiswa baru melalui kunjungan sekolah. Hasil penelitian mereka yang diberi judul Efektivitas Promosi Kunjungan Sekolah Pada Mahasiswa Baru Program Sarjana pada Perguruan Tinggi Xyz (Pendekatan Consumer Deeision Modd), menjelaskan bahwa kunjungan ke sekolah dinilai memberikan pengaruh signifikan terhadap keputusan memilih program studi pada perguruan tinggi $\mathrm{XYZ}^{3}$.

${ }^{2}$ Encep Sopandi, "Strategi Promosi Penerimaan Mahasiswa Baru Untuk PTS (Tinjauan atas Kegiatan Promosi PTS di Jawa Barat Tahun 2010)," MANAJERIAL 9, no. 18 (2011).

${ }^{3}$ Roni Jayawinangun dkk., "Efektivitas Promosi Kunjungan Sekolah Pada Mahasiswa Baru Program Sarjana Pada Perguruan Tinggi XYZ (Pendekatan Consumer Decision Model) Tahun 2014," Forum Ilmiah 11, no. 3 (2014): 352-253. 
Selanjutnya, Muhammad Muslih pada tahun 2015 meneliti tentang Pengembangan E-Marketing Penerimaan Mahasiswa Baru (PMB) dengan Menggunakan Metode Service Orieted Arditecture (SOA): Studi Kasus Pada STT Nusa Putra Sukabumi tahun 2015. Hasil penelitiannya menyimpulkan bahwa aplikasi ini membuat tingkat kepuasan calon mahasiswa meningkat sebesar $80 \%{ }^{4}$. D emikian beberapa riset sejenis yang telah dilakukan berkenaan dengan penerimaan mahasiswa baru khususnya pada aspek strategi promosi yang digunakan.

Atas dasar inilah penulis berinisiatif untuk melakukan penelitian sederhana dengan judul Pola Sosialisasi Perguruan Tnggi dalam Meningkatkan Jumlah Penerimaan Mahasiswa pada IAIN Palu. Permasalahan yang akan dikaji adalah: Bagaimana pola-pola sosialisasi penerimaan calon mahasiswa baru yang diterapkan di IAIN Palu? Pola sosialisasi yang bagaimana yang paling efektif terhadap keputusan calon mahasiswa masuk di IAIN Palu?

\section{Pembahasan}

Teori yang digunakan dalam mencermati efektivitas sosialisasi mahasiswa baru adalah teori perilaku konsumen. D alam konteks ini, perguruan tinggi dianggap sebagai sebuah lembaga formal yang menawarkan jasa pendidikan dan pengajaran kepada masyarakat. Masyarakat dalam hal ini adalah konsumen yang dalam memilih sebuah perguruan tinggi tentu memiliki alasan dan pertimbangan-pertimbangan dalam menjatuhkan pilihannya.

\section{Peilakukansumen}

Perilaku konsumen adalah sesuatu fenomena yang kompleks, karena menyangkut banyak variabel yang mempengaruhinya serta kecenderungannya untuk saling berinteraksi. Dengan demikian menentukan hubungan antara perilaku pembelian berulang dengan kepuasan pelanggan tidaklah mudah. Setidaknya ada dua alasan-menurutSutisnamengapaperilaku konsumen perlu dipelajari. Pertama, konsumen adalah titik sentral perhatian pemasaran. Mempelajari apa yang dibutuhkan dan diinginkan oleh konsumen pada saat ini merupakan hal yang sangat penting. Kedua, perkembangan

${ }^{4}$ Muhammad Muslih, "Pengembangan E-Marketing Penerimaan Mahasiswa Baru (PMB) Dengan Menggunakan Metode Service Oriented Architecture (SOA) : Studi Kasus Pada STT Nusa Putra Sukabumi Tahun 2015," Jurnal Nusantara, 2015, 11, http://jurnal.nusaputra.ac.id/ index.html. 
perdagangan saat ini menunjukkan bahwa lebih banyak produk yang ditawarkan daripada permintaan. Oleh karena itu sudah selayaknya perilaku konsumen menjadi perhatian penting dalam pemasaran. ${ }^{5}$

Menurut Assael sebagaimana dikutip dalam Sutisna ${ }^{6}$ ada tiga faktor yang mempengaruhi konsumen dalam membuat keputusan pembelian yaitu konsumen individu, lingkungan dan penerapan strategi pemasaran.

Model Perilaku Konsumen pada gambar 1 di atas menunjukkan adanya interaksi antara pemasar dengan konsumennya. Komponen pusat dari model tersebut adalah pengambilan keputusan yang terdiri atas proses merasakan dan evaluasi informasi merek produk, mempertimbangkan alternatif merek dapat memenuhi kebutuhan konsumen, dan pada akhirnya memutuskan merek apa yang akan dibeli. Terdapat 3 (tiga) faktor yang mempengaruhi pilihan konsumen yaitu:

a. Faktor individu, artinya pilihan untuk membeli suatu produk dengan merek tertentu dipengaruhi oleh hal-hal yang ada pada diri konsumen. Kebutuhan, persepsi terhadap karakteristik merek, sikap, kondisi demografis, gaya hidup dan karakterisitik kepribadian individu akan mempengaruhi pilihan inidividu terhadap berbagai alternatif merek yang tersedia.

b. Faktor lingkungan konsumen, yaitu pilihan konsumen terhadap merek dipengaruhi oleh lingkungan yang mengitarinya. Konsumen dalam membeli suatu produk, mungkin didasari oleh banyak pertimbangan misalnya, membeli suatu merek tertentu karena meniru teman sekolahnya atau mungkin juga tetangganya. Jadi interaksi sosial yang dilakukan oleh konsumen tersebut, akan turut mempengaruhi pilihannya terhadap suatu merek yang akan dibelinya.

c. Faktor stimulus pemasaran atau strategi pemasaran, dimana pemasar berusaha untuk mempengaruhi konsumen dengan menggunakan stimulus-stimulus pemasaran, misalnya, iklan agar konsumen bersedia memilih merek yang ditawarkan.

${ }^{5}$ Sutisna, Perilaku Konsumen \& Komunikasi Pemasaran (Bandung: PT. Remaja Rosdakarya, 2003), 4-5.

${ }^{6}$ Ibid. 
Selanjutnya Pemasar harus mengevaluasi strategi pemasaran yang dilakukan dengan melihat respon konsumen untuk memperbaiki strategi pemasaran dimasa yang akan datang.

\section{Strategj Rdkntmen Mahasisna Banu}

Kegiatan sosialisasi penerimaan calon mahasiswa baru merupakan bagian dari strategi yang diterapkan oleh perguruan tinggi guna merekrut para calon mahasiswa. Sebagai sebuah strategi, sosialisasi tentu memiliki tujuan sebagai target yang akan dicapai. Aspek strategis dalam penerimaan mahasiswa baru umumnya terdiri atas langkah-langkah: menganalisis sistuasi internal dan eskternal, penetapan tujuan, pemilihan dan penetapan strategi, komponen layanan pendidikan, biaya pendidikan, lokasi, dan promosi. Untuk lebih mengoptimalkan hasil dari strategi promosi, perlu dilakukan analisis situasi internal dan eksternal.

Carnoy berpendapat walaupun kita tidak banyak melihat peran pendidikan semata, ada saja kemungkian pendidikan itu makin dikaitkan dengan pekerjaan. ${ }^{7}$ Menurut Callaway, untuk mengatasi penganggur terdidik mungkin perlu diadakan perubahan kurikulum yang radikal, mengkaitkan lebih erat antara sekolah dengan masyarakat. ${ }^{8}$

Menurut Hallak, bidang pendidikan sebagai produsen jasa pendidikan, sama halnya dengan bidang-bidang aktivitas lainya, secara teoritis menimbulkan konsep biaya yang sama. Tetapi, pengamatan yang lebih cermat terhadap penerapan konsep biaya terhadap pendidikan mengungkapkan adanya tiga bentuk kesulitan yang melekat pada sifat aktivitas pendidikan itu sendiri dan terutama timbul dari definisi produksi pendidikan, identifikasi transaktor ekonomi yang berhubungan dengan pendidikan, dan kenyataan bahwa pendidikan mempunyai sifat-sifat pelayanan umum. Produsen pendidikan adalah lembaga pendidikan, dan yang menjadi konsumen pendidikan adalah peserta didik dan keluarga yang dapat dikatakan "membeli" pendidikan bagi anaknya.

${ }^{7}$ Martin. Carnoy, Education as Cultural Imperialism. (D. McKay Co, 1974), 96.

${ }^{8}$ Archibald Callaway, Educational Planning and Employed Youth, (Paris: UNESCO: 1971), 31

${ }^{9}$ Hallak, Jacques, ed., Educational Costs and Productivity: contributions to a seminar for professors of educational planning (economics) 
Jika perguruan tinggi dipandang sebagai produsen jasa pendidikan, maka dibutuhkan strategi pemasaran yang tepat untuk meyakinkan para calon konsumen. D isinilah pentingnya sosialisasi yang bertujuan untuk mempromosikan perguruan tinggi kepada masyarakat sehingga dapat memperoleh kepercayaan dari mereka dan bersedia menjadi konsumen.

Aspek strategis terpenting untuk mendapatkan mahasiswa baru bagi perguruan tinggi adalah kegiatan promosi. Promosi pada umumnya dipakai oleh badan usaha dengan motif meningkatkan keuntungan. Kegiatan promosi sebagai salah satu bagian dari strategi pemasaran dapat pula diterapkan dalam organisasiorganisasi nonlaba (termasuk pendidikan). Meskipun tujuantujuannya berbeda dengan usaha bisnis, tetapi prinsip-prinsip umum pemasaran dapat diterapkan langsung kepada organisasiorganisasi nonlaba. Menurut Alex Triyana, kegiatan promosi meliputi beberapa kegiatan yang kesemuanya termasuk dalam marketing commmication ${ }^{10}$ Pandangan lain menyatakan promosi adalah penyampaian informasi dari penjual kepada pembeli untuk mempengaruhi sikap-sikap dan tingkah laku, di mana tugas manajer promosi pemasaran adalah memberitahukan langanan sasaran, bahwa produk yang baik tersedia ditempat (place) yang benar dengan harga (price yang tepat. ${ }^{11}$

Menurut Kismono, bauran promosi terdiri dari enam variabel yaitu: ${ }^{12}$ pertama,Iklan, yaitu komunikasi non personal yang dibiayai sponsor (organisasi maupun individu) melalui berbagai media. Media yang dapat digunakan meliputi: surat kabar, televisi, dreemail (katalog, brosur), radio, majalah, outdoor displays (bilboard, poster), dan lain-lain.

Kedua, personal sellingatau penjualan personal yaitu komunikasi tatap muka langsung untuk mempromosikan barang atau jasa menemukan prospek penjualan, dan memberikan layanan pasca penjualan. Tiga karakteristik khusus penjualan personal

of the regional centres of Unesco, held at the International Institute for Educational Planning, (Paris: UNESCO, 1967), 2-4.

${ }^{10}$ Alex D. Triyana, "Menerapkan Strategi Marekting di Indonesia" (Makalah dalam Marketing Seminars: Jakarta,1987), 64-71

${ }^{11}$ Encep Sopandi, "Strategi...,94

${ }^{12}$ Gugup Kismono, Pengantar Bisnis, Edisi I, (Cetakan I; Yogyakarta: BPFE, 2001) 
adalah: 1) melibatkan hubungan yang hidup, cepat, dan interaktif antara dua orang atau lebih; 2) memungkinkan semua jenis hubungan berkembang menjadi lebih mendalam sehingga meningkatkan minat pelanggan; dan 3) Membuat pembeli merasa berkewajiban untuk mendengar wiraniaga dan memberikan respon balik.

Ketiga, promosi dari Mulut ke Mulut. Pola ini terjadi jika konsumen membicarakan, baik secara negatif maupun positifnya. Menurut penelitian-penelitian yang diakukan oleh Departemen Urusan Konsumen White House Office terungkap bahwa konsumen yang tidak puas akan menceritakan pengalaman buruknya kepada sembilan orang temanya.

Keempat, publicRdations atau hubungan masyarakat adalah fungsi manajemen yang mengevaluasi sikap masyarakat, mengambil kebijakan-kebijakan sesuai dengan kepentingan publik, dan mengambil tindakan-tindakan yang diperlakukan agar publik dapat memahami dan menerima produk perusahaan. Saat ini public relations semakin penting dalam perusahaan untuk menjembatani komunikasi antara perusahaan dengan pelanggan, relasi bisnis, pemerintah atau pihak eksternal yang lain.

Kelima, publisitas, yaknisegala bentuk informasi segala tentang individu, produk, organisasi yang mengalir kepada masyarakat melalui mass media tanpa membayar dan diluar kontrol sponsor. Publisitas merupakan bagian dari hubungan masyarakat. Publisitas mempunyai beberapa manfaat yaitu untuk menumbuhkan kesadaran konsumen akan produk perusahaan, membentuk citra positif, mendapatkan pengakuan atas karyawan dan prestasi mereka. mendorong orang-orang untuk berpartisipasi dalam proyek-proyek kemasyarakatan, atau pada saat tertentu untuk melawan pemberitaan-pemberitaan yang negatif.

Keenam,Promosi penjualan Promosi penjualan dapat merupakan sarana promosi yang efektif, tergantung pada karakteristik produknya. Jika konsumen dapat dipengaruhi setelah mencoba produk, mungkin promosi penjualan berupa pembagian contoh produk secara gratis, dapat efektif. Promosi penjualan adalah usaha untuk mempengaruhi konsumen dan pihak lain melalui aktifitas-atifitas jangka pendek, misalnya pameran dan pemberian contoh produk. Demonstrasi memasak atau demonstrasi penggunaan produk seringkali merupakan cara yang 
diterima konsumen dan biasa dilakukan ketika perusahaan melakukan pameran.

\section{MetodePenditian}

Penelitian ini menggunakan desain penelitian survey yang dikombinasikan dengan model analisis kualitatif deskriptif, yakni berupaya menghimpun data, mengolah dan menganalisa secara kualitatif dan mendefenisikannya secara kualitatif pula. ${ }^{13}$ Penelitian kualitatif umumnya lebih longgar terhadap instrumen pengumpulan data dan lebih fokus pada proses dari pada produk suatu objek penelitian, ${ }^{14}$ sehingga penelitian kualitatif dilakukan berdasarkan pengumpulan data akurat di lapangan. ${ }^{15}$ Penelitian kualitatif dapat didefinisikan sebagai suatu penelitian interpretatif terhadap suatu masalah, di mana peneliti merupakan sentral dari pengertian dan pemaknaan yang dibuat mengenai masalah itu.

Penelitian ini berlangsung di kota Palu tepatnya di Kampus IAIN Palu. Kampus ini dipilih karena merupakan satu-satunya perguruan tinggi Islam negeri di Sulawesi Tengah dan saat ini tengah dalam proses pertumbuhan setelah beralih status dari Sekolah Tinggi. Perubahan status kelembagaan ini berimplikasi terhadap pengembangan program studi, dan karena itu, upaya sosialisasi masih sangat perlu dilakukan guna "memperkenalkan kembali" profil lembaga ini kepada publik yang hingga saat ini masih banyak yang menyebutnya dengan STAIN (Sekolah Tinggi Agama Islam Negeri).

Populasi dalam penelitian ini adalah seluruh mahasiswa baru yang dinyatakan lulus dan mendaftar kembali yang berjumlah 1.359. Semua populasi dijadikan responden, namun setelah diverifikasi, yang layak dijadikan sebagai data penelitian hanya sebesar 1.196. Ini disebabkan beberapa hal diantaranya, responden lalai melengkapi datanya seperti, asal sekolah, asal daerah, pendapatan orang tua dan lain-lain. Peneliti memutuskan

13 Wardi Bachtiar, Metodologi Penelitian IlmuDakwah (cet.I; Jakarta: Logos, 1997), 21

${ }^{14}$ Noeng Muhadjir, Metodologi Penelitian Kualitatif,edisi IV, (cet.I; Yogyakarta: Rake Sarasin, 2000), 43

${ }^{15}$ Lihat: Robert Bodgan dan Steven J. Taylor, Instrduction to Qualitative Research Method, (New York' John Wiley \& Sons, 1975),h. 4; Fred N. Kaelinger, Foundation of Behavioral Research, (New York: Hold Rinehart and Winston, 1973), 525 
menggunakan 1.196 responden karena dipandang cukup representative mewakili varian populasi secara menyeluruh.

D ata yang dibutuhkan dalam penelitian ini dikumpulkan melalui metode: Kuesioner yang terdiri dari dua bagian. Pertama berisi tentang karakteristik responden, dan kedua berisi pertanyaan/ pernyataan tertulis di mana responden diminta untuk menjawab sesuai persepsi masing-masing. Di samping kuesioner, juga digunakan metode wawancara dan dokumentasi sebagai metode pendukung.

Dalam proses analisis data penulis akan berpijak pada syarat-syarat- sebagaimana yang dikemukakan Noeng Muhadjirobjektif, sistematis dan bersifat generalisasi. Generalisasi yang dimaksud adalah bahwa temuannya mempunyai sumbangan teoritik. ${ }^{16}$

Analisis data yang digunakan oleh peneliti menggunakan Analisis Interaktf Miles dan Hubeman Teknik analisis ini pada dasarnya terdiri dari 3 komponen yaitu: reduksi data, penyajian data dan penarikan serta pengujian kesimpulan. ${ }^{17}$

\section{Pda Sosialisasi Peneimaan Calon Mahasisna BanuIAIN Palu}

Upaya meningkatkan jumlah mahasiswa baru menjadi agenda penting di setiap perguruan tinggi, bukan hanya di perguruan tinggi swasta tetapi juga di perguruan tinggi negeri seperti IAIN Palu.Hal ini cukup beralasan mengingat ada sejumlah regulasi berkenaan dengan pengelolaan dan pengembangan perguruan tinggi menjadikan jumlah mahasiswa sebagai salah satu indikator penilaian.

IAIN Palu, telah melakukan langkah-langkah serius dalam upaya meningkatkan jumlah mahasiswa baru. Salah satu upaya yang dilakukan adalah mempromosikan lembaga melalui berbagai media, antara lain: surat kabar, panflet atau brosur (termasuk dalam kategori ini adalah spanduk), website, dan yang paling menonjol dan menelan biaya besar adalah sosialisasi dalam bentuk kunjungan ke sekolah-sekolah menengah atas (SMU, SMK, dan MA) baik negeri maupun swasta. Menurut penjelasan Ketua Lembaga

${ }^{16}$ Lihat: Noeng Muhadjir, Metodologi...,68

${ }^{17}$ Pawito, Penelitian Komunikasi Kualitatif (Yogyakarta: PT. LKiS Pelangi Aksara, 2007), 104. 
Penjaminan Mutu (LPM) IAIN Palu ${ }^{18}$-yang mengkoordinir pelaksanaan sosialisasi- kegiatan sosialisasi ini dilaksanakan sekitar 2 atau 3 bulan menjelang penerimaan mahasiswa baru dengan melibatkan sejumlah dosen yang terbagi ke dalam beberapa tim dan masing-masing tim menyebar ke sejumlah daerah kabupaten dan kota di wilayah provinsi Sulawesi Tengah. Pelaksanaan sosialisasi dilakukan dalam bentuk presentasi tentang: a) profil IAIN Palu di hadapan para siswa; 2) Ragam jalur pendaftaran mahasiswa baru (SPAN, UMPTKIN, Lokal); dan c) Syarat dan tata cara pendaftarannya. Di samping sosialisasi dalam bentuk presentasi, masing-masing tim juga membawa serta panflet dan spanduk untuk disebar dan dipajang di tempat-tempat yang dianggap strategis, terutama di sekolah-sekolah.

Jumlah sekolah yang dikunjungi oleh Tim Sosialisasi Penerimaan Mahasiswa Baru IAIN Palu Tahun 2017 sebanyak 131 sekolah yang tersebar pada 13 Kabupaten/Kota di wilayah Provinsi Sulawesi Tengah, dan satu Kabupaten di wilayah Provinsi Sulawesi Barat, yaitu Kabupaten Mamuju. Kategori sekolah yang dikunjungi adalah Sekolah Lanjutan Tingkat Atas (SLTA), yang terdiri dari Sekolah Menengah Atas (SMA), Sekolah Menengah Kejuruan (SMK), Madrasah Aliyah (MA), dan Pondok Pesantren (Ponpes), baik yang berstatus negeri maupun swasta.

Jika pola sosialisasi ini diamati dengan menggunakan teori promosi yang dikemukakan oleh Kismono ${ }^{19}$ maka dapat dipetakan bahwa pola sosialisasi yang digunakan oleh IAIN Palu meliputi:

a. Iklan, yakni komunikasi non personal melalui berbagai media. Media yang dapat digunakan meliputi: surat kabar, televisi, dan lian-lain. Dalam hal ini IAIN Palu menggunakan media internet, panflet, brosur atau spanduk yang dipajang di tempat-tempat yang dianggap strategis. Data dari kuesioner menunjukkan bahwa 7,94\% responden mengenal IAIN Palu melalui panflet, dan 5,43\% melalui internet.

b. Pessonal seling atau penjualan personal,yakni komunikasi tatap muka langsung untuk mempromosikan barang atau jasa menemukan prospek penjualan, dan memberikan layanan

18 Ketua Lembaga Penjaminan Mutu (LPM) IAIN Palu, "Wawancara", Palu, 08 Agustus 2017

${ }^{19}$ Lihat: Gugup Kismono, Pengantar Bisnis, Edisi I, (Cetakan I; Yogyakarta: BPFE, 2001) 
pasca penjualan. Model ini dilakukan oleh IAIN Palu pada saat berkunjung langsung ke SLTA, bertatap muka dan berdialog secara interaktif dengan para calon mahasiswa. Hal ini didukung dengan data yang diperoleh melalui kuesioner yang menunjukkan hasil bahwa 44,3\% responden mengakui bahwa sekolah mereka pernah dikunjungi oleh tim sosialisasi penerimaan mahasiswa baru dari IAIN Palu.

D ua pola tersebut, iklan dan pessanal selling merupakan pola sosialisasi yang dalam pelaksanaannya dilakukan secara terencana dan terprogram oleh IAIN Palu serta dibiayai langsung oleh lembaga. Namun demikian, fakta menunjukkan bahwa calon mahasiswa baru mengenal IAIN Palu ternyata tidak sepenuhnya bersumber dari program promosi atau sosialisasi yang dilaksanakan oleh pihak kampus secara langsung sebagaimana pola yang disebutkan di atas. Sebagian responden justru memperoleh informasi melalui orang tua (15,3\%), dan yang paling menonjol adalah dari teman (46,57\%).

Dalam konteks ini, dapat diduga bahwa ada pola promosi atau sosialisasi lain yang terjadi secara tidak terencana oleh lembaga tetapi memiliki dampak yang cukup signifikan. Dalam teori promosi yang dikemukan oleh Kismono, ${ }^{20}$ ada dua pola promosi yang dapat dihubungkan dengan kasus ini, yaitu:

a. Promosi dari mulut ke mulut. Promosi dari mulut kemulut terjadi jika konsumen membicarakan, baik secara negatif maupun positif. Artinya, hal-hal positif berkenaan dengan IAIN Palu yang berkembang dari pembicaraan individu ke individu lain, apakah itu mahasiswa, dosen, orang tua siswa, atau siapapun yang telah mengenal lembaga ini. Meskipun pembicaraan itu tidak dimaksudkan sebagai upaya promosi, tetapi secara tidak langsung hasilnya akan berdampak positif dalam memperkenalkan IAIN Palu kepada masyarakat.

b. Publisitas, yakni segala bentuk informasi tentang individu, produk, organisasi yang mengalir kepada masyarakat melalui mass media tanpa membayar dan diluar kontrol sponsor/ lembaga kampus. Artinya, pemberitaan-pemberitaan yang muncul di mass media seperti televisi, radio, surat kabar, dan lain-lain yang memberikan informasi kepada publik tentang keberadaan IAIN Palu. Informasi yang dimaksud di sini bukan

\footnotetext{
${ }^{20}$ Ibid.
} 
iklan yang sengaja di pajang di mass media, tetapi pemberitaanpemberitaan positif yang berhubungan dengan lembaga, misalnya saat melaksanakan kegiatan besar seperti PIONIR, seminar, dan lain-lain. Termasuk dalam kategori ini ketika dosen-dosen IAIN Palu diundang sebagai nara sumber di televisi atau pada acara-acara keagamaan yang diselenggarakan di tengah masyarakat. Termasuk kiprah alumni atau dosen yang memegang jabatan publik, seperti Ketua MUI, Ketua KPU, Bupati, Anggota legislatif, dan lain-lain.

Dengan demikian, secara garis besarnya pola sosialisasi penerimaan mahasiswa baru terjadi dalam dua bentuk-dalam perspektif teori promosi yang dikemukakan oleh Kismonoyaitu:a) sosialisasi terencana dan terprogram yang diwujudkan dalam bentuk iklan dan pessonal selling dan b) sosialisasi tidak terencana dalam bentuk promosi dari mulut ke mulut dan publisitas.

1. Efektivitas Pola Sosialisasi Penerimaan Mahasiswa Baru

Sosialisasi penerimaan calon mahasiswa baru bertujuan untuk menarik para calon mahasiswa baru, dalam hal ini para lulusan SLTA, untuk mendaftarkan diri pada lembaga yang dipromosikan, dalam hal ini IAIN Palu. Oleh karena itu, tolak ukur efektivitasnya diukur dari sejauhmana pola tersebut mampu mempengaruhi atau menarik minat calon mahasiswa mendaftarkan diri pada IAIN Palu.

Langkah awal dari sebuah upaya sosialisasi adalah memperkenalkan lembaga IAIN Palu kepada publik. Pertanyaan yang diajukan dalam kuesioner berkenaan dengan hal ini adalah item nomor 1, yakni dari manakah para responden memperoleh informasi untuk pertama kalinya tentang IAIN Palu? Pertanyaan ini bersifat semi terbuka karena responden diberikan alternatif jawaban dalam bentuk pilihan (orang tua, teman, panflet, internet dan sosialisasi di sekolah), tetapi juga diberi peluang untuk mengisi jawaban lain jika jawaban tidak ditemukan pada pilihan yang tersedia. Jawaban yang diperoleh, sebagian besar responden memperoleh informasi dari teman (46,57\%).

Apakah hal ini menunjukkan bahwa pola sosialisasi yang tidak terprogram (penyampaian dari mulut ke mulut dan/atau publisitas) lebih efektif dibanding pola sosialisasi terprogram (panflet, internet atau pun kunjungan sekolah) dalam 
memperkenalkan lembaga kepada calon mahasiswa? Hal ini masih perlu ditelusuri dan dianalisis lebih lanjut.

Bila dicermati data wilayah pelaksanaan sosialisasi, terlihat bahwa ada 4 wilayah yang frekuensinya lebih menonjol, yaitu: Kota Palu, Donggala, Sigi dan Parigi Moutong. Jika data ini dibandingkan dengan data responden (mahasiswa baru yang mendaftar) berdasarkan wilayah, akan ditemukan hal yang sama di mana jumlah responden yang menonjol juga berasal dari 4 wilayah tersebut meskipun tidak berbanding lurus dalam ranking.

Dengan demikian, dapat diasumsikan bahwa pada prinsipnya sebagian besar responden sudah mengenal keberadaan IAIN Palu melalui teman-teman sepergaulan mereka, namun informasi secara detil dan sistematis mereka peroleh melalui tim sosialisasi atau brosur dan panflet, terutama berkenaan dengan informasi penerimaan mahasiswa baru. Itulah sebabnya, pertanyaan tentang dari mana mereka memperolah informasi awal tentang IAIN Palu, sebagian besar dijawab "dari teman". Jawaban ini relatif menonjol pada semua wilayah, bukan hanya di wilayah yang masuk dalam peringkat 4 (empat) besar.

Sinergi antara pola sosialisasi dari mulut ke mulut yang kemudian disempurnakan melalui kunjungan sekolah oleh tim sosialisasi, cukup efektif dalam menarik perhatian para calon mahasiswa untuk mendaftar di IAIN Palu. Sehingga daerah-daerah dengan jumlah sekolah yang banyak dikunjungi, seperti Kota Palu, Kabupaten Donggala, Kabupaten Sigi dan Kabupaten Parigi Moutong, menempati posisi teratas dalam jumlah pendaftaran mahasiswa baru dengan selisih angka yang cukup signifikan dari daerah lain.

Oleh karena itu, sosialisasi dalam bentuk kunjungan sekolah masih efektif digunakan bahkan lingkup jangkauannya perlu dikembangkan. Berdasarkan data dari Lembaga Penjaminan Mutu (LPM), pada tahun 2017 jumlah sekolah yang dikunjungi masih relatif sedikit bila dibandingkan dengan jumlah SLTA yang ada di Sulawesi Tengah. D ata Badan Pusat Statistik (BPS) Provinsi Sulawesi Tengah menunjukkan: jumlah Sekolah Menengah Umum (SMU) dan Madrasah Aliyah (MA) yang berstatus negeri untuk wilayah Sulawesi Tengah mencapai 176 sekolah, dan yang berstatus swasta mencapai 319, sehingga jumlah total SMU dan MA sebesar 495 sekolah. Selanjutnya, jumlah Sekolah Menengah Kejuruan 
(SMK) yang berstatus negeri mencapai 95 sekolah dan yang swasta mencapai 86 sekolah, sehingga total SMK sebesar 181 sekolah. Dengan demikian, jumlah SLTA yang tersebar di tiap Kota/ Kabupaten mencapai 676 sekolah.

Memperhatikan jumlah total SLTA pada tabel 15 di atas, jelas sekali bahwa program sosialisasi persanal selling melalui kunjungan sekolah oleh Tim Sosialisasi Penerimaan Mahasiswa Baru IAIN Palu, hanya menjangkau19,4\% dari total SLTA yang ada. Bahkan bila diperhatikan detail data pada masing-masing wilayah, justru prosentase kunjungan yang tinggi berada di wilayah kota Palu dan kabupaten yang terdekat dengannya seperti D onggala, Sigi dan Parigi Moutong. Pada tabel 16 dipaparkan secara rinci perbandingan jumlah SLTA yang ada di Sulawesi Tengah dengan SLTA yang dikunjungi oleh Tim Sosialisasi.

Idealnya, persanal sdling melalui kunjungan sekolah dapat menjangkau hingga 60\% dari jumlah SLTA jika tidak dapat mencapai seluruhnya. D an seyogyanya, target utama sosialisasi kunjungan sekolah diprioritaskan pada daerah-daerah yang jauh dari Kota Palu, karena untuk wilayah Kota Palu dan sekitarnya sebagian besar masyarakat sudah mengenal IAIN karena kampusnya berada di tengah kota dan berlokasi di tempat yang sangat strategis dan mudah dikenali, belum lagi mahasiswanya yang tersebar dan menetap di dalam kota.

Apabila karena alasan biaya operasional yang tinggi sehingga kunjungan sekolah tidak maksimal, maka perlu dipertimbangkan alternatif lain dengan memperbanyak brosur atau panflet sehingga jangkauannya bisa lebih luas. Artinya sosialisasi dalam bentuk iklan lebih diperluas, sedangkan model pasanal selling dikurangi, cukup di beberapa daerah saja yang memang dianggap belum mengenal IAIN Palu. D engan cara ini, pengenalan terhadap lembaga serta informasi seputar penerimaan mahasiswa baru di tiap tahunnya dapat diterima secara merata di seluruh wilayah provinsi Sulawesi Tengah.

Namun demikian, pengenalan lembaga hanyalah sebuah pengantar dari tujuan sosialisasi, tujuan utamanya adalah menarik minat para calon mahasiswa untuk mendaftar pada lembaga yang sudah dikenalnya itu. Pertanyaannya kemudian, faktor apakah yang mendorong mereka mendaftarkan diri di IAIN Palu? Apakah keinginan sendiri atau karena rekomendasi orang lain, misalnya, 
orang tua, teman atau karena propaganda tim sosialisasi yang berkunjung ke sekolah? Hasil kuesioner (nomor 3) menunjukkan bahwa sebagian besar responden $(80,6 \%)$ mendaftarkan diri atas keinginan sendiri. Jawaban ini hampir merata pada semua responden terlepas dari latar belakang sosial ekonomi dan juga daerahnya. Salah satu indikator dalam melihat kategori sosial ekonomi mereka adalah latar belakang pekerjaan orang tua, dan ternyata hal ini tidak banyak berpengaruh.

Kecenderungan memilih atas dasar keinginan sendiri lebih menonjol pada semua kategori profesi orang tua. $\mathrm{Hal}$ ini menunjukkan bahwa meskipun faktor "teman" sangat efektif sebagai media sosialisasi pengenalan lembaga, tetapi belum tentu efektif dalam mempengaruhi keputusan responden dalam memilih perguruan tinggi. Sebagian besar responden sudah bersikap rasional, sehingga dalam memilih perguruan tinggi diputuskan atas keinginan sendiri tanpa dipengaruhi oleh orang lain. Maka yang perlu ditelusuri adalah faktor apa yang menjadi pertimbangan utama mereka dalam memilih IAIN Palu?

Hasil kuesioner (nomor 5) menunjukkan 57,61\% responden menyatakan bahwa banyaknya varian fakultas dan jurusan menjadi alasan mereka memilih IAIN Palu. Hal ini sejalan dengan jawaban kuesioner (nomor 6), 79,35\% responden mendaftar atas pertimbangan utama kesesuaian bidang keilmuan dengan minat mereka. Prospek lapangan kerja tampaknya tidak cukup berpengaruh dalam memilih perguruan tinggi, hanya 1,17\% responden yang menjadikannya pertimbangan utama. Sekali lagi, latar belakang pekerjaan orang tua tidak banyak berpengaruh, meskipun sejumlah responden menjadikan faktor ekonomi (biaya pendidikan) sebagai pertimbangan utama, tetapi jumlahnya relatif kecil $(14,3 \%)$.

Dengan demikian, faktor yang paling menonjol dalam menarik minat para calon mahasiswa baru adalah ketersediaan program studi yang bervariasi sehingga mereka memiliki banyak alternatif pilihan bidang keilmuan yang sesuai dengan minat dan bakat mereka. 


\section{Kesimpulan}

Berdasarkan hasil analisis data, dapat disimpulkan bahwa: petama, pola sosialisasi yang diterapkan di IAIN Palu adalah dengan memanfaatkan media, baik itu media cetak maupun media elektronik, disamping itu juga melakukan sosialisasi melalui kunjungan-kunjungan ke sekolah dan madrasah yang tersebar di Provinsi Sulawesi Tengah, bahkan sampai ke Provinsi Sulawesi Barat, khusunya di Kab. Mamuju dan sekitarnya.

Kectua, pola sosialisasi yang efektif dalam memperkenalkan lembaga kepada publik adalah pola sosialisasi tidak terprogram dalam bentuk: a) promosi dari mulut ke mulut, dan b) publisitas. Namun dalam hal sosialisasi penerimaan mahasiswa baru pola sosialisasi terprogram yang diselenggarakan secara reguler setiap menjelang penerimaan mahasiswa baru dalam bentuk: a) iklan dan; b) persanal sellingmelalui kunjungan sekolah-sekolah, masih cukup efektif. Sedangkan faktor yang menjadi pertimbangan utama untuk mendaftarkan diri di IAIN Palu adalah ketersediaan program studi yang sesuai dengan minat mereka. 


\section{Daftar Pustaka}

Bachtiar, Wardi, Metoddog Penditian IlmDakwah cet.I; Jakarta: Logos, 1997.

Bodgan, Robert dan Steven J. Taylor, Instrduction to Qualitative ReearchMethod, New York' John Wiley \& Sons, 1975.

Callaway, Archibald, Educational Planningand Employed Yatth Paris: UNE SCO : 1971.

Carnoy, Martin,.Education as Cultural Imperialism D. McKay Co, 1974.

D inas Pendidikan dan Kebudayaan Daerah Provinsi Sulawesi Tengah, tahun 2016

Hallak, Jacques, ed., Educational Costs and Productivity: contributions to a seminar for professors of educational planning (economics) of the regional centres of Unesco, held at the International Institute for Educational Planning, Paris: UNESCO , 1967.

Jayawinangun, Roni, dkk., "Efektivitas Promosi Kunjungan Sekolah Pada Mahasiswa Baru Program Sarjana Pada Perguruan Tinggi XYZ (Pendekatan Consumer Decision Model) Tahun 2014," Fonumllmah 11, no. 3 (2014).

Kaelinger, Fred N., Faundation of Bdhavioral Research New York: Hold Rinehart and Winston, 1973

Kismono, G ugup, Pengantar Bissis Edisi I, Cetakan I; Yogyakarta: BPFE, 2001.

Muhadjir, Noeng, Metoddog Penditian Kualitatif,edisi IV, cet.I; Y ogyakarta: Rake Sarasin, 2000.

Muslih, Muhammad, "Pengembangan E-Marketing Penerimaan Mahasiswa Baru (PMB) D engan Menggunakan Metode Service Oriented Architecture (SOA) : Studi Kasus Pada STT Nusa Putra Sukabumi Tahun 2015," Jumal Nusantara, 2015, 11, http:/ / jurnal.nusaputra.ac.id/ index.html.

Pawito, Penditian Komnikasi Kualitatif, Yogyakarta: PT. LKiS Pelangi A ksara, 2007.

Sopandi, Encep, "Strategi Promosi Penerimaan Mahasiswa Baru Untuk PTS (Tinjauan atas Kegiatan Promosi PTS di Jawa Barat Tahun 2010)," MANAJERIAL 9, no. 18 (2011). 